Creative Commons User License: CC BY-NC-ND

Abstracted by: EBSCOhost, Electronic Journals Service (EJS), Google Scholar, Journal Seek, Scientific Commons,

Food and Agricultural Organization (FAO), CABI and Scopus

http://eoi.citefactor.org/10.11226/v23i2
Journal of Agricultural Extension

Vol. 23 (2) April, 2019

ISSN(e): 24086851; ISSN(Print); 1119944X

http://journal.aesonnigeria.org

http://www.ajol.info/index.php/jae

Email: editorinchief@aesonnigeria.org

\title{
Model of Sustainable Private Forest Management in Yogyakarta Special Regency,
}

Indonesia

https://dx.doi.org/10.4314/jae.v23i2.8

\section{Widayanto, Budi*}

Universitas Sebelas Maret Surakarta, Central Java, Indonesia

Department of Agribusiness, Universitas Pembangunan Nasional "Veteran" Yogyakarta, Yogyakarta

Special Region, Indonesia

Email: budiwidayanto99@gmail.com, Phone: +62 818254673

\section{Karsidi, Ravik.}

Department of Education, Universitas Sebelas Maret Surakarta, Central Java, Indonesia, Email: ravik@uns.ac.id, Phone: +62 8122650300

\section{Kusnandar, Kusnandar}

Department of Agribusiness, Universitas Sebelas Maret Surakarta, Central Java, Indonesia, Email: kusnandar@yahoo.com, Phone: +62 8156720359

\section{Sutrisno, Joko}

Department of Agribusiness, Universitas Sebelas Maret Surakarta, Central Java, Indonesia, Email: jokosutrisno@staff.uns.ac.id, Phone: +62 8122643757

${ }^{*}$ Corresponding author

\section{Abstract}

The study analysed the relationships between variables i.e. community empowerment, community institutions, stakeholder support, farmer participation in the management of private forests, and generate a sustainable private forest management model. The research method was the survey method with the area sample taken with purposive sampling and farmer samples taken with multistage random sampling resulting in 270 samples. Data collected were analysed using descriptive statistics and structural equation model. The results of the study show that sustainable private forest management is directly influenced by farmer participation (0.65), community institutions (0.20), and stakeholder support has no direct influence (0.07). Stakeholder support indirectly influence sustainable private forest management through mediation variable (0.39). This study found that community compliance with the value of local institution, where private forests are the ancestral heritage that must be preserved can change the harvest system that considers sustainability aspects.

Keywords: Community institution, stakeholder support, sustainable private forest management

\section{Introduction}

Forest cover almost one third of the world's land area and almost all of them are inhabited by indigenous and rural people who have customary rights to these forests. The community has developed a way of life and traditional knowledge that is in harmony with the forest environment (Chao, 2012). In most region of the world, forests are managed with agroforestry systems and serve as the livelihoods of rural communities by providing employment, energy, nutritious food, 
Creative Commons User License: CC BY-NC-ND

Abstracted by: EBSCOhost, Electronic Journals Service (EJS), Google Scholar, Journal Seek, Scientific Commons,

Food and Agricultural Organization (FAO), CABI and Scopus
Journal of Agricultural Extension

Vol. 23 (2) April, 2019

ISSN(e): 24086851; ISSN(Print); 1119944X

http://journal.aesonnigeria.org

http://www.ajol.info/index.php/jae

Email: editorinchief@aesonnigeria.org

http://eoi.citefactor.org/10.11226/v23i2

and various ecosystems (FAO, 2014). More than 10,000 years after the agricultural revolution began; millions of rural smallholders in developing countries still earn money in the forests and wilderness by farming (Wunder et al. 2014).

The size of Indonesia's forest area reaches 120 million hectares and experiences degradation and deforestation so that only $75 \%$ is left so that it needs to be repaired to maintain its existence.

Forest is an important buffer for human life with its various functions (Tahajudin, 2015). Based on its status, forests are divided into state forests and rights forest that are generally called private forest. Private forests are plantations that grow on the land owned by the people and the community has the freedom to manage them. Rural communities have the ability to manage private forests, but the community also has limitation in capital, management, planning and marketing. Therefore, rural communities need to be assisted in institutional development, business development, technology guidance, education and training, and access to the markets (Puspitojati et al., 2014).

Interaction and dependence between rural communities and forest products is a challenge in balancing the use of the forest products with forest conservation. Forest resources play an important role in the livelihoods of local communities for various products. Forest function as the main source of primary and secondary income for rural household (Moe et al. 2016; Langan et al., 2016; Hlaing et al., 2017; Toe et al. 2017). Local communities do business in the forest with a pattern that has become a culture of society with an orientation of economic and social needs, while environmental aspects are often an obstacle due to the limited ability of local communities. Furthermore, Moe et al. (2016) stated that community forestry (CF) programs should be encouraged to reduce dependence on natural forest. CF programs must be driven by participation of low and middle income household. The community development program is expected to change behaviour that leads to sustainable forest management.

The activity of integrating behavioural theory into practice of sustainable forest management can be used to overcome social challenges. Interventions are carried out to change attitudes and practice or to maintain desired behaviour (O'Brien et al., 2017). The increasing diversity of nonindustrial private forest owners (PFOs) in Europe has been recognized by policy makers and the forestry sector in general. This owner's typology has been developed to provide an understanding of the diversity of attitudes, value, beliefs, goals and behavior of the owner (Fickoa et al., 2019). Community-based forest management, such as Community Forest Enterprises (CFEs), has the potential to generate positive socio-environmental and economic outcomes. Increased sustainability of CFEs operation requires increased capacity, technical assistance from the government and sustainable financial assistance (Cubbage et al., 2015).

In forestry development, the main factors that must be considered are forests and their communities, where both have different functions and interests. To produce sustainable private forest management, forests and communities must be in the same ecosystem policy so as to provide economic, social and environmental benefits. Efforts to develop private forests need to be synergized between traditional private forest businesses and environmental needs. The development of a private forest is directed at a sustainable private forest management model that can change community behaviour by considering economic, social and environmental aspects (IFCC, 2013; NRDC, 2013; FSC, 2015; LEI, 2016). 
Creative Commons User License: CC BY-NC-ND

Abstracted by: EBSCOhost, Electronic Journals Service (EJS), Google Scholar, Journal Seek, Scientific Commons,

Food and Agricultural Organization (FAO), CABI and Scopus
Journal of Agricultural Extension

Vol. 23 (2) April, 2019

ISSN(e): 24086851; ISSN(Print); 1119944X

http://journal.aesonnigeria.org

http://www.ajol.info/index.php/jae

Email: editorinchief@aesonnigeria.org

Model, in operational research terminology are defined as an abstraction of an actual situation. The model shows direct and indirect relationships and causal links (Eryatno, 2012). In this study, the effects of various factors on sustainable private forest management in the form of models were examined. The management model is expected to be able to change the behaviour of the community in conducting a private forest business by paying attention to economic, social, and environmental aspects. In the concept of behaviour change according to Lewin's theory, a person's behaviour is influenced by his personal and environmental circumstances. Individuals and the environment form a psychological field, so that groups and environments form social fields. Social behaviour occurs and simultaneously produces social entities in the group. Thus, group behaviour is a function of the total field situation at a given time (Schultz and Schultz, 1992). Skinner (2013) formulated that behaviour is the response or reaction of a person to stimulus (external stimulation).

In the community's view, the existence of private forest is an ancestral heritage that must be preserved. Giving the private forest to the next generation is a way of looking at the community providing lessons on responsibility for sustainability. The community has a history of long and multi-generational interaction with the environment in overcoming environmental uncertainties. Traditional knowledge refers to the accumulation of intergenerational knowledge that guides the community in interactions with the surrounding environment. Environmental management through their own systems based on traditional knowledge, practice, rules and beliefs for generations (Nakhashima, 2012; Chao, 2012). Value in the form of general rules, norms, sanctions, and interrelationships in groups that encourage individual actions is to achieve positive results for sustainability. Community development needs to be considered the importance of community specific factors, such as social capital, collective performance, where social capital is stimulus for collective action. Well-managed forests have tremendous potential to contribute to sustainable development and a green economy (FAO, 2014).

In managing private forest, the community already has an awareness of the ability to manage traditionally with the same feeling as a community in rural areas. This awareness can be used as capital in community empowerment. Empowerment is carried out as an effort to meet the needs of the community so that they have the ability to make choices and control the environment.

Empowerment is also a process of strengthening capacity to improve social, economic, cultural and political well-being carried out by the community together with the government and other stakeholders (Mardikanto, 2013). Interpersonal communication is an important way of communication for someone to implement a community empowerment strategy towards the desired results. In this communication process policy makers will be easier to advise their client to make changes towards empowerment (Nasor, 2016).

Communication from "farmers to farmers" is an important method for obtaining information between farmers; farmers also usually meet in community meetings such as community meetings (Adong et al., 2013). This shows the importance of the existence of groups in society to provide information for the advancement of individuals and society at large. Farmer-based organizations are increasingly becoming an important vehicle for developing farmers (Etwire et al. 2013). In order for farmer-based organizations to be attractive to farmers, it seems they must work to achieve certain goals, have good group cohesion, good flow of information, noble leadership and be able to provide real support to its member farmers.

Empowerment of human resources plays a role in developing farmer participation, building communication with farmers and farmer groups, equality of social status with farmers. Group 
Creative Commons User License: CC BY-NC-ND

Abstracted by: EBSCOhost, Electronic Journals Service (EJS), Google Scholar, Journal Seek, Scientific Commons,

Food and Agricultural Organization (FAO), CABI and Scopus
Journal of Agricultural Extension

Vol. 23 (2) April, 2019

ISSN(e): 24086851; ISSN(Print); 1119944X

http://journal.aesonnigeria.org

http://www.ajol.info/index.php/jae

Email: editorinchief@aesonnigeria.org

dynamics affect farmer participation; the relationship of group dynamics with the participation of female farmer group members in the program concludes that the level of group dynamics is related to participation in the high category (Nurcahyanti et al. 2017). Individuals tend to be more easily influenced by their groups than the influence of lectures or coercion to change. Research conducted by Taleshi (2015), forests in the Iranian desert show success, that is in the framework of planning an area that is precise, comprehensive, and sustainable through involvement in planning. In a participatory approach, the community is involved in project thinking and planning, monitoring and evaluation. Assistance in the form of subsidies can be considered as a necessary condition but not sufficient conditions for the adoption of sustainable technology (Devi et al. 2014).

The results of a study conducted by Hlaing et al. (2017) provides information that politicians and decision makers that local residents can be considered as one of the stakeholders of conservation activities and are designed i a participatory community-based forest management (CBFM) strategy that balances the conservation and use of forest products. Forest management activities that involve many rural communities, both as managers and as forest workers, are the key to the success of forest management. The realization of this will increase the important role of the forestry sector in national development (Puspitojati et al. 2014). The sustainability paradigm of the European Landscape Convention calls for increased involvement of all affected parties combined with active leadership to promote social values (Bjarstig et al. 2016). A program will be sustainable if the beneficiaries are directly involved from the start, and the community is actively involved from the start in solving the problem.

\section{Objectives of the Study}

The purpose of this study was to describe and analyse the relationships between variables that influence sustainable private forest management and create a model of sustainable private forest management.

\section{Hypotheses}

Ho1: Sustainable private forest management is significantly influenced by community institution, farmer participation, and stakeholder support

Ho2: Farmer participation is significantly influenced by community institution, group dynamics, and stakeholder support

Ho3: Group dynamics is significantly influenced by community institution, community empowerment, and stakeholder support

Ho4: Community empowerment is significantly influenced by community institution and stakeholder support

\section{Methodology}

This research used survey methods, according to Babbie (2013) survey research is probably the best method available to the social researcher who is interested in collecting original data for describing a population too large to observe directly. The area sampling method uses purposive sampling with the consideration that the area has a private forest management pattern that varies resulting from 3 sub-districts and 9 villages. Multistage cluster sampling, which is the selection of samples in several stages considering population identification and population size (Creswell, 2015) resulted in 270 respondents. Data collection used an instrument with a Likert scale to measure attitude scale.

This study analysed two exogenous variables and four endogenous variables, namely: 
Creative Commons User License: CC BY-NC-ND

Abstracted by: EBSCOhost, Electronic Journals Service (EJS), Google Scholar, Journal Seek, Scientific Commons,

Food and Agricultural Organization (FAO), CABI and Scopus
Journal of Agricultural Extension

Vol. 23 (2) April, 2019

ISSN(e): 24086851; ISSN(Print); 1119944X

http://journal.aesonnigeria.org

http://www.ajol.info/index.php/jae

Email: editorinchief@aesonnigeria.org

http://eoi.citefactor.org/10.11226/v23i2

1. Community institutions with indicators such as property right, rules of representation, jurisdictional boundary, and leaderships.

2. Stakeholders support with indicators like cooperation, motivators, potential function, and program fluency.

3. Community empowerment with indicators such as aspects/scope of empowerment, performance/empowerment systems, beneficiaries of empowerment

4. Group dynamics has group goals, group structure, task functions, group founding and development, group cohesiveness, group atmosphere, pressure on groups, group effectiveness, disguised intentions as indicators

5. Farmer participation comprises volunteerism, involvement, willingness, opportunity, ability

6. Sustainable private forest management had indicators such as environmental, social, economic sustainability.

The percentage index indicated that respondents' assessment of all variables was very high on numbers that is (80-100) \%. The second analysis used the Structural Equation Modelling-Partial Least Squares (SEM-PLS). The SEM-PLS is a causal modelling approach that aims to maximize the variation of the latent criterion variable which can be explained by latent predictor variables (Sholihin et al. 2013).

The estimation result of the relationship between factors showed that the value of validity and reliability meets the requirements. The results of the validity test of all research instruments with Pearson Correlation are in the interval 0.44-0.72; all values are above the requirements (>0.37). While the reliability with Cronbach's Alpha is in the interval 0.91-0.95, all values are above the requirements $(>0.60)$. Goodness of fit model using the program statistical analysis tool is an index and a measure of the good relationship between latent variables (inner model) shows that the model is fit. The result of fit model, that is: average path coefficient $(A P C)=0.37$, average $R$ squared $(A R S)=0.59$, average adjusted $R^{2}(A A R S)=0.59$, average block VIF $(A V I F)=1.73$ (ideally $\leq 3.3$ ); average full collinearity VIF (AFVIF) $=2.87$ ideally $\leq 3.3$ ). These results indicate that the output shows the goodness of fit model criteria has been met.

\section{Results and Discussion}

\section{Socio-economic Characteristics of Farmers Who Cultivate Private Forests and Assessment Index}

The socio economic characteristic of farmers who cultivate private forest in the research area showed that 228 people $(84.44 \%)$ were men. This shows that men dominate private forest concessions. The average age of farmers who cultivate private forests is 49.16 years old; the average age indicates that the farmers are in productive age. The education condition of the average farmer is in secondary education. With secondary level education indicates that farmers already have sufficient ability to obtain information for the progress of their business. While the average size of household is 4 people, this will affect the spirit of the farmer in working to improve the welfare of their family. For the area of the private forest ownership, farmers have an average area of 3,056.79 $\mathrm{m}^{2}$; while for other area (paddy fields and yard) is $1,636.15 \mathrm{~m}^{2}$. With this private forest area, farmers can intensively cultivate the private forest. While the non-private forest area can be used as an alternative to increase income so that it can reduce the pressure on the use of private forest. 
Creative Commons User License: CC BY-NC-ND

Abstracted by: EBSCOhost, Electronic Journals Service (EJS), Google Scholar, Journal Seek, Scientific Commons,

Food and Agricultural Organization (FAO), CABI and Scopus
Journal of Agricultural Extension

Vol. 23 (2) April, 2019

ISSN(e): 24086851; ISSN(Print); 1119944X

http://journal.aesonnigeria.org

http://www.ajol.info/index.php/jae

Email: editorinchief@aesonnigeria.org

Sustainable private forest management

Farmer participation

Group dynamics

Community empowerment

Stakeholder support

Community institution

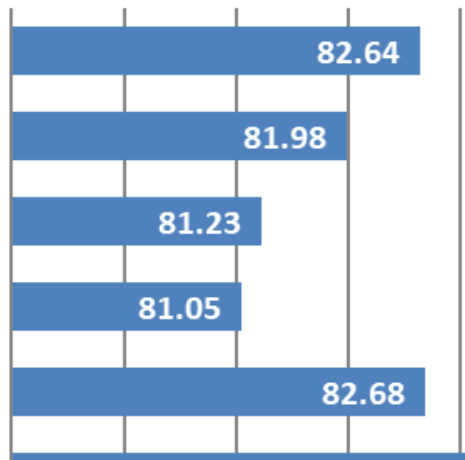

83.86

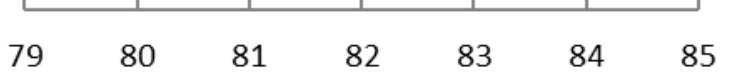

Figure1: Percentage of variable values based on calculation of percentage index formulas $(n=270)$

Figure 1 shows that all variables show very high values $(>80 \%)$ and the highest value is community institutions (83.86\%). Community institutions have an important role in encouraging other variables to work, especially those that are directly related, namely community empowerment, group dynamics, and sustainable private forest management. Community institution as a natural process that grows and develops in the community has created social and cultural conditions that have enabled the success of sustainable private forest management. The condition of the community institution begins with the emergence of awareness of each family unit of the private forest manager in maintaining the existence of the private forest as a legacy and needs to be inherited for future generations. Taylor and Grieken (2015), in their study, found that local and non-local institutions could jointly mediate the socio-cultural and institutional sources that underlie farmer participation in the program. Success in regional economic development programs that are oriented towards green economy (environmental protection and ecological security, encourage economic modernization) and traditional energy occupy important positions (Pakina, 2014).

\section{Model, Direct and Indirect Relationships between Variables in Sustainable Private Forest Management}

Based on the estimation of the relationship of the factors that influence the sustainable private forest management, the model is generated, 
Creative Commons User License: CC BY-NC-ND

Abstracted by: EBSCOhost, Electronic Journals Service (EJS), Google Scholar, Journal Seek, Scientific Commons,

Food and Agricultural Organization (FAO), CABI and Scopus
Journal of Agricultural Extension

Vol. 23 (2) April, 2019

ISSN(e): 24086851; ISSN(Print); 1119944X

http://journal.aesonnigeria.org

http://www.ajol.info/index.php/jae

Email: editorinchief@aesonnigeria.org

http://eoi.citefactor.org/10.11226/v23i2

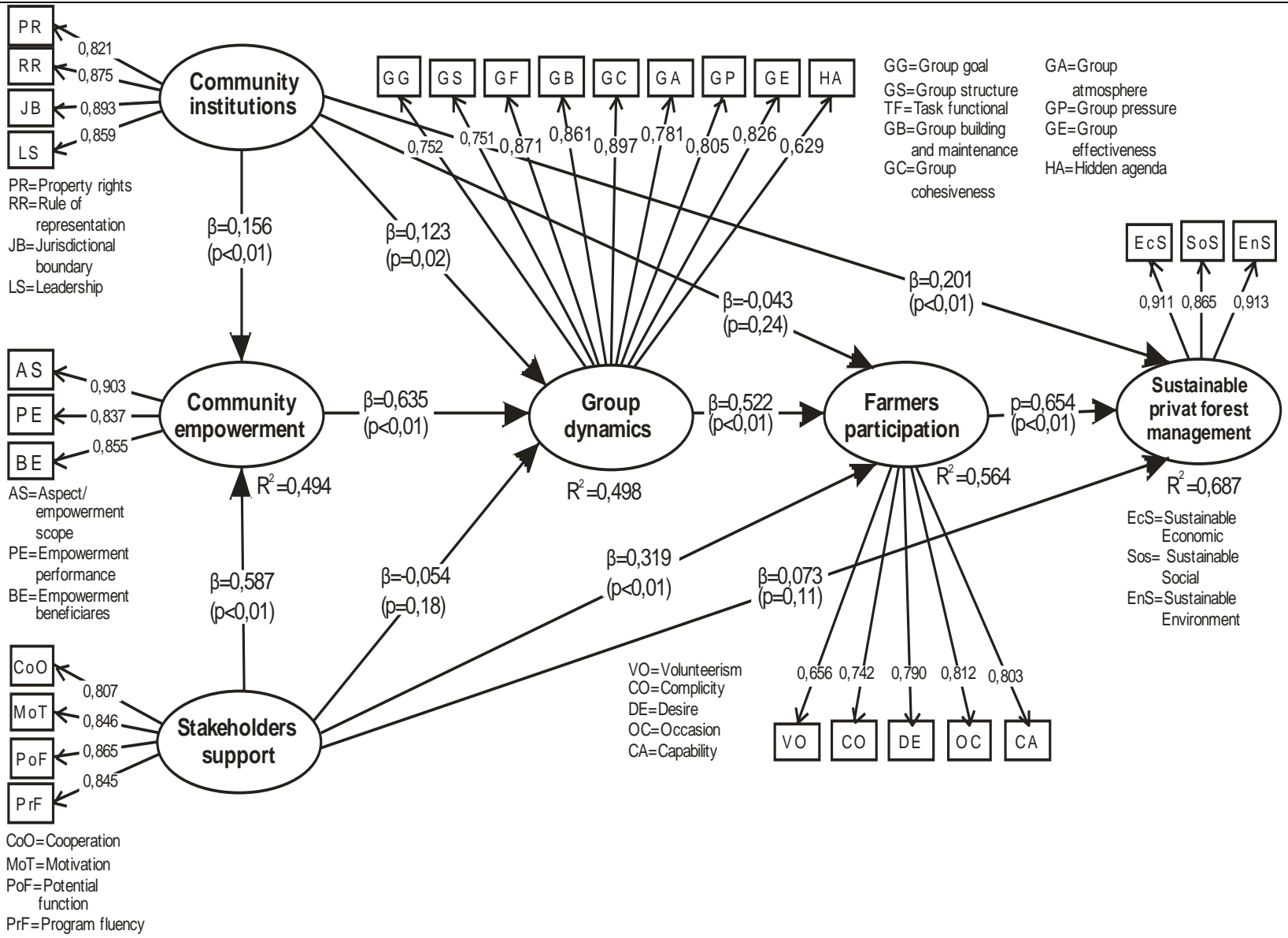

Figure 2: Sustainable private forest management model

The indirect output and total effect, which explains the influence of relationships between variables (predictor variables with responses) with indicators of the type of influence and the magnitude of the coefficient of influence and the nature of relationships between variables can be seen in Table 1. Community empowerment influences sustainable private forest management indirectly through mediation (group dynamics and farmer participation) with a total effect of 0.22 . Community institutions directly influence sustainable private forest management by 0.20 and indirectly through mediation (community empowerment, group dynamics, farmer participation) by 0.05 so that the total effect is 0.25 . Stakeholder support directly influences sustainable private forest management by 0.07 and indirectly through mediation (community empowerment, group dynamics, and farmer participation) by 0.32 so that the total effect is 0.39 . Group dynamics indirectly influence sustainable private forest management through mediation (farmer participation) by 0.34 and farmer participation directly influences sustainable private forest management by 0.65 . 
Creative Commons User License: CC BY-NC-ND

Abstracted by: EBSCOhost, Electronic Journals Service (EJS), Google Scholar, Journal Seek, Scientific Commons,

Food and Agricultural Organization (FAO), CABI and Scopus
Journal of Agricultural Extension

Vol. 23 (2) April, 2019

ISSN(e): 24086851; ISSN(Print); 1119944X

http://journal.aesonnigeria.org

http://www.ajol.info/index.php/jae

Email: editorinchief@aesonnigeria.org

http://eoi.citefactor.org/10.11226/v23i2

\begin{tabular}{|c|c|c|c|c|c|c|c|c|c|}
\hline \multicolumn{2}{|c|}{ Type of variable } & \multicolumn{3}{|c|}{ Mediation } & \multicolumn{4}{|c|}{ Type of influence } & \multirow{2}{*}{$\begin{array}{l}\text { Total } \\
\text { Effect }\end{array}$} \\
\hline Predictor & Response & M1 & M2 & M3 & Direct & & Indirect & & \\
\hline CE & SPFM & GD & FP & & & 0.217 & & & 0.217 \\
\hline $\mathrm{Cl}$ & SPFM & CE & GD & FP & 0.201 & -0.028 & 0.042 & 0.034 & 0.249 \\
\hline SS & SPFM & CE & GD & FP & 0.073 & 0.209 & -0.019 & 0.127 & 0.390 \\
\hline GD & SPFM & FP & & & & 0.341 . & & & 0.341 \\
\hline FP & SPFM & & & & 0.654 & & & & 0.654 \\
\hline CE & FP & GD & & & & 0.331 & & & 0.331 \\
\hline $\mathrm{Cl}$ & FP & CE & GD & & -0.043 & 0.064 & 0.052 & & $0.073^{\star *}$ \\
\hline SS & FP & $\mathrm{CE}$ & GD & & 0.319 & -0.028 & 0.194 & & 0.485 \\
\hline GD & FP & & & & 0.522 & & & & 0.522 \\
\hline CE & GD & & & & 0.635 & & & & 0.635 \\
\hline $\mathrm{Cl}$ & GD & CE & & & 0.123 & 0.099 & & & 0.222 \\
\hline SS & GD & CE & & & -0.054 & 0.373 & & & 0.318 \\
\hline $\mathrm{Cl}$ & $\mathrm{CE}$ & & & & 0.156 & & & & 0.156 \\
\hline SS & $\mathrm{CE}$ & & & & 0.587 & & & & 0.587 \\
\hline
\end{tabular}

${ }^{*} \mathrm{P} \leq 0.05$. Source: Field Survey, 2018

$\mathrm{Cl}=$ Community Institution; SS = Stakeholder support; CE = Community Empowerment; GD = Group

Dynamics; FP = Farmer Participation; SPFM = Sustainable Private Forest Management.

\section{Influence of Community Institutions, Farmer Participation, and Stakeholder Support for Sustainable Private Forest Management}

Sustainable private forest management is significantly influenced by community institutions $(\beta=$ $0.20)$ and farmer participation $(\beta=0.65)$, while stakeholder support $(\beta=0.07)$ is not significant with $R^{2}$ of 0.69 . Stakeholder support influences sustainable private forest management by mediating community, group dynamics and farmer participation variables with a total effect of 0.39 .

This shows that local values in sustainable forestry are in accordance with the needs of the forest for the environment. Knowledge of indigenous peoples has been defined as institutionalized local knowledge that has been built and inherited from one generation to another (Ajani et al. 2013). The private forest history begins with planting by community leaders and develops into mass activities with family units. Then it developed in the forest farmer group organization and subsequently developed into a private forest management unit. The attachment of society to their organizations and territories has become a force in maintaining a sustainable private forest. Farmer participation has an effect on sustainable private forest management; this shows that farmers' awareness to behave sustainably is in line with the values needed in the management of private forests. Although local communities are not the main stakeholder in decision making in most activities, their role seems to have increased in activities where participatory approaches are implemented (Boutthavong et al., 2017).

Stakeholder support has no significant effect; this indicates the complexity of private forest management. The interests and needs of all stakeholders are not the same so that it requires a certain strategy to give satisfaction to most stakeholders. According to Baker (2012), in practice, difficulties arise in understanding because of differences in attention, needs, abilities, resources and history of each stakeholder. Stakeholders lack the ability to manage issues that describe the present and future needs of the community. This can be caused by the wide range of roles carried out by stakeholders and the need for sustainability concepts so it is often not aligned between the support and the need for the concept of sustainable private forest. 
Creative Commons User License: CC BY-NC-ND

Abstracted by: EBSCOhost, Electronic Journals Service (EJS), Google Scholar, Journal Seek, Scientific Commons,

Food and Agricultural Organization (FAO), CABI and Scopus
Journal of Agricultural Extension

Vol. 23 (2) April, 2019

ISSN(e): 24086851; ISSN(Print); 1119944X

http://journal.aesonnigeria.org

http://www.ajol.info/index.php/jae

Email: editorinchief@aesonnigeria.org

http://eoi.citefactor.org/10.11226/v23i2

The main challenge for Reducing Emissions from Deforestation and Forest Degradation (REDD) in developing countries is to balance the strengths of various stakeholder in decision making.

Research by Boutthavong et al., (2017) found that the role of stakeholder in decision making is not balanced. All stakeholders must have the same knowledge and understanding of existing issues and produce collective policies, so that they can develop the concept of "fair trade" and will give influence in taking part in the benefits. Bal et al., (2013), pointed out that sustainability is a complex concept in the project and there are many diverse stakeholders. Some stakeholders are generally recognized as important, but there are others who are not always considered important and in the decision-making process can lead to failure to address sustainability issues.

In the development of community forests, all stakeholders must pay attention to the interests of community forests as a community business unit and their environmental function needs. Based on the history of the existence of community forests, stakeholders must be able to create an ecosystem for the efforts made by the community from community forests. Communities and rural areas must be developed in businesses based on community forests so that they can provide support towards sustainable community forest management.

\section{Influence of Community Institutions, Group Dynamics, and Stakeholder Support to Farmer Participation}

Farmer participation is significantly influenced by the group dynamics and stakeholder support, while the community institution has no significant effect. Variable group dynamics $(\beta=0.52)$ and stakeholder support $(\beta=0.32)$ have a significant effect and community institutions $(\beta=-0.04)$ have no effect with $R^{2}$ of 0.564 . Simulation by eliminating the direct relationship between community institutions and farmer participation, community institutions has influence in farmer participation by mediating community empowerment and group dynamics with a total effect of 0.13 .

Group dynamics significantly influences farmer participation. The development of inheritance values about the private forest that must be preserved has given direction to the community in participating. Stakeholder support significantly influences farmer participation. This shows that stakeholder support has an interest in encouraging community activities in various ways. In addition, private sector participation can increase opportunities to harmonize their investment to support the development of REDD+ and reduce the negative impacts on forests and the environment (Boutthavong et al. 2017).

Community institutions have developed well at the family unit level and developed in groups and communities in their views of the private forest as ancestral heritage that must be preserved. But these conditions do not directly influence the form of farmer participation in activities. Not all households have the same level and type of local knowledge. Therefore, giving awareness and sharing of experiences among community members is important in enhancing the application of indigenous knowledge for adaptation to change (Amare, 2018). Institution is social capital which can be used as a foundation in the process of community development, especially in mobilizing farmers for participation. However, participation is a process of community involvement which needs to be made aware of behavior change to participate in accordance with the needs of participation.

Ajani et al. (2013) states in local knowledge practices can be used in adapting to the effects of climate change among farmers in sub-Saharan Africa. However, not all local community practices 
Creative Commons User License: CC BY-NC-ND

Abstracted by: EBSCOhost, Electronic Journals Service (EJS), Google Scholar, Journal Seek, Scientific Commons,

Food and Agricultural Organization (FAO), CABI and Scopus
Journal of Agricultural Extension

Vol. 23 (2) April, 2019

ISSN(e): 24086851; ISSN(Print); 1119944X

http://journal.aesonnigeria.org

http://www.ajol.info/index.php/jae

Email: editorinchief@aesonnigeria.org

http://eoi.citefactor.org/10.11226/v23i2

are beneficial for the sustainable development of local communities, and not all local knowledge

provides the right solution for the problems given. Organizing local communities for projects to improve agricultural resilience to climate change must utilize traditional skills and knowledge effectively, thereby increasing prospects for community empowerment and independent development in the face of climate variability.

\section{Influence of Community Institution, Community Empowerment, and Stakeholder Support to Group Dynamics}

Group dynamics is significantly influenced by community institutions and community empowerment, while the influence of stakeholder support is not significant. Variable of community institutions $(\beta=0.12)$ and community empowerment $(\beta=0.64)$, while stakeholders support $(\beta=-$ 0.05 ) with $R^{2}$ of 0.50 . Stakeholder support influences the group dynamics by mediating community empowerment by 0.32 . The community institution variable influences the group dynamics, where the private forest is a business carried out by the family unit. Family relations (husband and wife) are very decisive in making decisions on the management of private forest businesses. Furthermore, communication that occurs within the family unit develops in the institutions of farmer groups and community institutions. This is driven by the intensity of community interaction in social and religious life, resulting in a shift in the form of communication from family institutions to group institutions. The intensity of communication in family units, group units, and communities is affecting the farmer group dynamics.

Community empowerment variable influence the group dynamics, community empowerment provides additional knowledge and technology, the ability to assess and evaluate and awareness (self-awareness), so as to provide an encouragement to activity. Government support in terms of funding, programs, and employment also provides development conditions and affects the conditions of the group dynamics. Besides that, community empowerment provides the ability of the community to get information, takes advantage of opportunities in the development of their business and the ability to anticipate change. One variable that does not affect group dynamics is the stakeholder supports variable, this is probably due to the number of stakeholders related to the private forest business and does not function optimally so it does not affect the group dynamics. Some stakeholders that are intensively linked include: facilitators from nongovernmental organizations, forestry extension workers, self-help forestry extension agents. The community believes that the existence of a private forest is an ancestral heritage that must be preserved and a place for economic business so that the dynamics group has stronger local cultural factors. The culture that emerged as a result of community interaction that has been going on for a long time has made the community more independent in managing the private forest.

Stakeholder support needs to be coordinated to overcome various group problems in maintaining the existence of a sustainable private forest. Farmers and counselling workers must be actively and jointly involved in the design of agroforestry projects for effective improvement and that agroforestry counselling services must be promoted so that farmers feel the use of technology to improve technology. Enhancing agroforestry technology can be achieved by providing quality and reliable agroforestry counselling services and the effective involvement of farmers and field staff support in agroforestry projects, are key to improve the technology. Development of agroforestry strategies and strengthening coordination and partnerships among stakeholders involved in agroforestry (Kakhobwe et al. 2016). 
Creative Commons User License: CC BY-NC-ND

Abstracted by: EBSCOhost, Electronic Journals Service (EJS), Google Scholar, Journal Seek, Scientific Commons,

Food and Agricultural Organization (FAO), CABI and Scopus
Journal of Agricultural Extension

Vol. 23 (2) April, 2019

ISSN(e): 24086851; ISSN(Print); 1119944X

http://journal.aesonnigeria.org

http://www.ajol.info/index.php/jae

Email: editorinchief@aesonnigeria.org

http://eoi.citefactor.org/10.11226/v23i2

Influence of Community Institution and Stakeholder Support to Community Empowerment Community empowerment significantly influenced community institutions and stakeholder support with the influence of community institutions $(\beta=0.16)$ and stakeholders support $(\beta=0.59)$ with $R^{2}$ of 0.49 . The influence of community institutions can be seen from the influence of the culture of life where private forest management is determined by family institutional units from the planting planning process to harvesting. With high community interaction, especially in social religious activities, family unit communication activities develop at the group level and extend to the social institutions of the community. The community has a habit of planting trees as a form of responsibility for the inheritance of their private forest from the previous generation, where private forest has economic functions and also must be preserved for the next generation. For the community, forests are their identity and forests are not just a collection of timber plants which can be traded at any time. Habits that exist in the community include: planting for the needs of posterity, harvesting 1 tree planting 2 to 5 trees, having trees as a form of social status in the community, and so on. Whereas stakeholder support through various programs from the government and the role of extension workers from government, non-governmental organizations, and non-governmental forestry extension agents have provided an increase in the ability of communities to access science, technology, information in the context of developing private forest businesses.

Based on path analysis, the big role is farmer participation, group dynamics, community empowerment, and stakeholder support. Whereas the community institution has a smaller role than the coefficient value. This shows that community institution factors need to be supported by those who are directly interested in the success of sustainable private forest management. Whereas stakeholder support has a big influence in encouraging and facilitating sustainable private forest management through empowerment activities and encouragement in farmer participation. Although the role of community institutions is not large in the direct and indirect influence of sustainable private forest management, community institutions have an important role to play in sustainable behaviour. In the culture of the community, the private forest is not just a timber tree plantation that produces economic benefits but has the value of community pride as the identity of the forest community. Forests have the function of preserving the environment through existing trees to preserve springs. Besides, the community also has a belief (myth) that around the source of the spring there are guardian creatures so that the condition of the forest and springs are maintained. By maintaining and planting trees around the source of the spring, nature will last. The existence of local wisdom values that have existed for a long time has influenced people's behaviour in encouraging the success of sustainable private forest management. Family units as the smallest unit of community institutions in carrying out private forest businesses have high compliance with the sustainability management of private forests.

The compliance is in a form of maintaining the attitude of ancestral heritage and adaptation to its natural environment to manage private forests in a sustainable manner. In the management of the private forest there has been a shift in tree harvesting patterns from clear-cut harvesting patterns to cutting patterns as needed and shifting to sustainable cutting patterns, that is harvesting based on tree economic age. The element of community compliance with the value of the private forest as the ancestral heritage that must be inherited from the next generation has guided the community to the behaviour in managing private forests in a sustainable manner. 
Creative Commons User License: CC BY-NC-ND

Abstracted by: EBSCOhost, Electronic Journals Service (EJS), Google Scholar, Journal Seek, Scientific Commons,

Food and Agricultural Organization (FAO), CABI and Scopus
Journal of Agricultural Extension

Vol. 23 (2) April, 2019

ISSN(e): 24086851; ISSN(Print); 1119944X

http://journal.aesonnigeria.org

http://www.ajol.info/index.php/jae

Email: editorinchief@aesonnigeria.org

\section{http://eoi.citefactor.org/10.11226/v23i2}

Sustainable private forest management model was influenced directly and indirectly through various mediating factors, namely community institutions, stakeholder support, community empowerment, group dynamics, and farmer participation. The sustainable private forest management model is influenced by farmer participation and community institutions, while the simulation of stakeholder support influences the mediation of community empowerment and farmer participation. Farmer participation is influenced by group dynamics and stakeholder support, while community institutions have influence on the mediation of community empowerment and group dynamics. The success of sustainable private forest management is supported by the strong compliance of the family unit as a private forest manager.

Further research need to be carried out on the role that must be performed by stakeholders, given the many interests in the management of the private forest and the functioning of forest ecosystems.

\section{References}

Adong, A., Mwaura, F., Okoboi, G. (2013). What factors determine membership to farmer groups in Uganda? Evidence from the Uganda census of agriculture 2008/9". Journal of Sustainable Development, 6 (4), 37-55.

Ajani, E.N., Mgbenka, R.N., and Okeke, M.N. (2013). Use of indigenous knowledge as a strategy for climate change adaptation among farmers in Sub-Saharan Africa: Implications for policy. Asian Journal of Agricultural Extension, Economics \& Sociology, 2(1), 23-40.

Amare, Z. Y. (2018). Indigenous knowledge of rural communities for combating climate change impacts in West Central Ethiopia. Journal of Agricultural Extension, 22 (1), 181-195. https://dx.doi.org/10.4314/jae.v22i1.16.

Babbie, E. (2013). The Basic of Social Research. (13 ${ }^{\text {th }}$ ed.). Canada: Nelson Education, Ltd. 229.

Baker, C., Gaydos, M., McLaughlin, J., Gilhuly, K., Elardo, N. I., Malekafzali, S., Tamburrini, A. L., Vonasek, K., White, S. (2012). Guideance and best parctices for stakeholder participation in health impact assesment version 1.0. Stakeholder participation working group of The

American Workshop. Oakland. C.A., 3. https://humanimpact.org/wpcontent/uploads/2012/03/HIA-Best-Practices-2012.pdf.

Bal, M., Bryde, D., Fearon, D., Edward Ochieng, E. (2013). Stakeholder engagement: Achieving sustainability in the construction sector. Sustainability, 6, 695-710. doi:10.3390/su5020695

Bjarstig, T., Kvastegard, E. (2016). Forest social values in a Swedish rural context: The private forest owners' perspective. Forest Policy and Economics, 65 (2016), 17-24.

Boutthavong, S., Hyakumura, K., Ehara, M. (2017). Stakeholder participation in REDD+ readiness activities for three collaborative projects in Lao PDR. Forests, 8, 150, 1-19. doi:10.3390/f8050150

Chao, S. (2012). Forest peoples: Numbers across the world. Forest Peoples Programme 1c Fosseway Business Centre, Stratford Road Moreton-in-Marsh GL56 9NQ United Kingdom.

Creswell, J. (2015). Riset Pendidikan: Perencanaan, Pelaksanaan, dan Evaluasi Riset Kualitatif dan Kuantitatif. Edisi ke-5. (Soetjipto, H., P. \& Soetjipto, S., M., translator). Yogyakarta: Pustaka Pelajar. 293-294. Translation for Educational Research, Planning, Conducting, and Evaluating Quantitative and Qualitative. $5^{\text {th }}$ edition.

Cubbage, F. W., Davis, R. R., Paredes, D. R., Mollenhauer, R., Elsin, Y. K., Frey, G. E., Hernandez, I. A. G., Hurtado, H. A., Cruz, A. M. S., Salas, D. N. C. (2015). Community forestry enterprises in Mexico: Sustainability and competitiveness. Journal of Sustainable Forestry, 34: 623-650. http://dx.doi.org/10.1080/10549811.2015.1040514 
Creative Commons User License: CC BY-NC-ND

Abstracted by: EBSCOhost, Electronic Journals Service (EJS), Google Scholar, Journal Seek, Scientific Commons,

Food and Agricultural Organization (FAO), CABI and Scopus
Journal of Agricultural Extension

Vol. 23 (2) April, 2019

ISSN(e): 24086851; ISSN(Print); 1119944X

http://journal.aesonnigeria.org

http://www.ajol.info/index.php/jae

Email: editorinchief@aesonnigeria.org

http://eoi.citefactor.org/10.11226/v23i2

Devi, P.I.; Solomon, S. S., Jayasree, M G. (2014). Green technologies for sustainable agriculture: Policy options towards farmer adoption. Indian Journal of Agricultural Economics, 69(3), 414-425.

Eryatno. (2012). IImu Sistem: Meningkatkan Mutu dan Efektifitas Manajemen (4 ${ }^{\text {th }}$ Ed.) Surabaya: Guna Widya. 51.

Etwire, P.M., Dogbe, W.,. Wiredu, A. N., Martey, E., Etwire, E., Owusu, R. K., Wahaga, E. (2013). Factors influencing farmer's participation in agricultural projects: The case of the agricultural value chain mentorship project in the Northern Region of Ghana. Journal of Economics and Sustainable Development, 4(10), 36-44.

Food and Agricultural Organization (FAO). 2014. State of the world's forest: Enhancing the socioeconomic benefits from forests. Food and Agricultural Organization of United Nations. Rome. 2, 7, 48.

Fickoa, A., Lidestav, G., Dhubháinc, A. N., Karppinend, H., Zivojinovicf, I., Westin, K. (2019). European private forest owner typologies: A review of methods and use. Forest Policy and Economics. 99, 21-31. http://dx.doi.org/10.1016/j.forpol.2017.09.010

Forest Stewardship Council. (2015). Marketing info pack 2015. http://www.ic.fsc.org. 5.

Haryadi, F. T., Widiati, R., Kusumastuti, T. A. (2019). Beef cattle farmers' group cohesion in Bantul and Sleman Regencies Yogyakarta Special Region, Indonesia. Journal of Agricultural Extension. 23(1), 223-229. https://dx.doi.org/10.4314/jae.v23i1.19

Hlaing, Z. C., Kamiyama, C., Saito, C. (2017). Interaction between rural people's basic needs and forest products: A case study of the Katha District of Myanmar. International Journal of Forestry Research. 2017, Article ID 2105012, 18 pages.

https://doi.org/10.1155/2017/2105012

Indonesian Forestry Certification Cooperation (IFCC). (2013). Sustainable Forest ManagementRequirements. Nomor Referensi IFCC ST 1001:2014, Bogor, Jawa Barat, Indonesia, 20-26.

Ivande, P. D., Olaolu, M. O. and Igbokwe Edwin M. (2019). Technological changes in farming among the tiv farming households in Nigeria. Journal of Agricultural Extension. 23(1), 1-12. https://dx.doi.org/10.4314/jae.v23i1.1

Kakhobwe, C.M., Kamoto, J. F., Njoloma, J. P., Ozor, N. (2016). Scaling up agroforestry farming systems: Lessons from the Malawi agroforestry extension project. Journal of Agricultural Extension, 20(1), 153-162. Http://dx.doi.org/ 10.4314/jae.v20i1.13

Langat, D. K., Maranga, E. K., Aboud, A. A., Cheboiwo, J. K. (2016). Role of forest resources to local livelihoods: The case of East Mau forest ecosystem, Kenya. International Journal of Forestry Research, 2016, Article ID 4537354, 10 pages.

http://dx.doi.org/10.1155/2016/4537354

Lembaga Ekolabel Indonesia. (2016). Pengelolaan Hutan Berbasis Masyarakat Lestari. Bahan Pelatihan bagi Fasilitator untuk Pengembangan Community institution dan Penyiapan Sertifikatsi Hutan. Masamba, Desember 19-23, 2016. 1-10.

Mardikanto, T., (2013). Pemberdayaan Masyarakat oleh Perusahaan: Acuan bagi Praktisi, Akademisi, dan Pemerhati Program CSR. Surakarta: Sebelas Maret University Press. 153, 219.

Moe, K. T., Liu, J. (2016). Economic contribution of non-timber forest products (NTFPs) to rural livelihoods in the Tharawady District of Myanmar. International Journal of Sciences. 5 (1), 12 21. DOI: $10.18483 /$ ijSci.904

Nakashima, D. J., McLean, K. G., Thulstrup, H., Castillo, A. R., Rubis, J. T. (2012). Weathering uncertainty: traditional knowledge for climate change assessment and adaptation. Paris and Darwin: UNESCO and UNU. 27-34. 
Creative Commons User License: CC BY-NC-ND

Abstracted by: EBSCOhost, Electronic Journals Service (EJS), Google Scholar, Journal Seek, Scientific Commons,

Food and Agricultural Organization (FAO), $\mathrm{CABI}$ and Scopus
Journal of Agricultural Extension

Vol. 23 (2) April, 2019

ISSN(e): 24086851; ISSN(Print); 1119944X

http://journal.aesonnigeria.org

http://www.ajol.info/index.php/jae

Email: editorinchief@aesonnigeria.org

http://eoi.citefactor.org/10.11226/v23i2

Nasor, M. (2016). Pemberdayaan masyarakat melalui komunikasi interpersonal. Al-Adyan, 11(1), 17-35. Retrieved Pebruari 6, 2019 from

ejournal.radenintan.ac.id/index.php/alAdyan/article/view/143

Natural Resources Development Center (NRDC). (2013). Modul: Konsep dan kebijakan pengelolaan hutan produksi lestari dan implementasinya (Sustainable Forest Management/ SFM). Jakarta: Program Terestrial The Nature Concevancy Indonesia. 9.

Nurcahyanti, P., Lestary, E., Sutarto. (2017). Hubungan group dinamics dengan partisipasi anggota kelompok wanita tani dalam program kawasan rumah pangan lestari (KRPL) Di Kecamatan Tasikmadu Kabupaten Karanganyar. Jurnal Agritexts, 41(1), 55-69.

O’Brien, L., Morris, J., Marzano, M., Dandy, N. (2017). Promoting sustainability behaviours through forestry. Forestry, 90, 88-98. doi:10.1093/forestry/cpw030.

Pakina, A. A. (2014). Green economy's prospects in Russia: case of Baikal Area, Journal of Sustainable Development of Energy, Water and Environment Systems, 2(2), 139-151. http://dx.doi.org/10.13044/j.sdewes.2014.02.0013

Puspitojati, T., Mile, M. Y., Fauziah, E., Darusman, D. (2014). Hutan Rakyat: Sumbangsih Masyarakat Pedesaan untuk Hutan Tanaman. Yogyakarta: Penerbit Kanisius. 21, 22, 30, 95, 96.

Rugema, S. H., Sseguya, H. and Kibwika, P. (2018). Determinants of smallholder farmers' participation in rice value chains in Uganda. Journal of Agricultural Extension, 22 (2), 62-71. https://dx.doi.org/10.4314/jae.v22i2.6

Schultz, D.P., Schultz, S. E. 1992. A History of Modern Psychology (5 $5^{\text {th }}$ Ed.), Florida: Jovanovich Inc. 407-408.

Sholihin, M. and Ratmono, D. (2013). Analisis SEM-PLS dengan WarpPLS 3.0 untuk Hubungan Nonlinier dalam Penelitian Sosial dan Bisnis. Yogyakarta: Andi Offset. 6-7.

Skinner, B.F. (2013). Ilmu Pengetahuan dan Perilaku Manusia. (Maufur, M. A., translator). Yogyakarta: Pustaka Pelajar. 174-177. Translation for Science and Human Behavior. Free Press Edition 1965.

Tahajuddin, U. (2015). Pengelolaan sumber daya hutan: Suatu tantangan. In: Hidayat, H. (Ed), Pengelolaan hutan lestari: Partisipasi, kolaborasi, dan konflik. Jakarta: Yayasan Pustaka Obor Indonesia. 12-42.

Taleshi, M. (2015). Participatory planning approach for sustainability of the desert regions forest planting in the North East of Iran, Sarayan. OIDA International Journal of Sustainable Development Canada, 8(9), 39-41.

Taylor, B. M., Grieken, M. V. (2015). Local institutions and farmer participation in agrienvironmental schemes. Journal of Rural Studies, 37, 10-19.

Toe, M. T., Kanzaki, M. (2017). Livelihood of local communities and their dependence on dry forests in the central dry zone, Myanmar. International Journal Sustainable Future for Human Security, 5(1), 22-31.

Wästerlund, D. S. (2018). Factors explaining the interest of adult offspring in succeeding their parents as forest owners. Forests, 9(11), 668. doi:10.3390/f9110668

Wunder, S., Angelsen, A., Belcher, B. (2014). Forests, livelihoods, and conservation: Broadening the empirical base. World Development, 64, S1-S11.

http://dx.doi.org/10.1016/j.worlddev.2014.03.007. 